\title{
Calmodulin antagonists stimulate renin secretion and inhibit renin synthesis in vitro
}

\author{
ROBERTO DELLA BRUNA, FLORENCE PINET, PIERRE CORVOL, AND ARMIN KURTZ \\ Physiologisches Institut der Universität Zurich, Zurich, Switzerland; College de France, Paris, France; \\ and Physiologisches Institut der Universität, W-8400 Regensburg, Germany
}

\begin{abstract}
Della Bruna, Roberto, Florence Pinet, Pierre Corvol, and Armin Kurtz. Calmodulin antagonists stimulate renin secretion and inhibit renin synthesis in vitro. Am. J. Physiol. 262 (Renal Fluid Electrolyte Physiol. 31): F397-F402, 1992.To find out whether calmodulin activity could be a common denominator for the cellular control of renin secretion and synthesis, we have examined the effects of calmodulin antagonists on the secretion and the synthesis of renin in primary cultures of mouse juxtaglomerular (JG) cells. We found that the calmodulin antagonists calmidazolium (CMDZ), $N$-(6-aminohexyl)-5-chloro-1-naphthalene-sulfonamide (W-7), and trifluoperazine (TFP) strongly stimulated renin release from isolated JG cells with a rank order of potency CMDZ $>$ TFP > $\mathrm{W}-7$. With the same order of potency as on renin secretion, CMDZ, TFP, and W-7 also inhibited de novo synthesis of renin. This decrease of renin synthesis went in parallel with a general inhibition of protein synthesis in the cultured JG cells. A comparable inhibition of total protein synthesis and renin synthesis as with CMDZ was achieved with cycloheximide. Cycloheximide, however, did not alter renin secretion within $20 \mathrm{~h}$ of incubation. Taken together, our findings suggest that inhibition of calmodulin activity exerts a powerful stimulatory effect on the exocytosis of renin in renal JG cells. Calmodulin activity on the other hand is also essentially required for protein and renin synthesis in JG cells. It is not very likely therefore that calmodulin activity positively links renin synthesis and renin secretion in JG cells.
\end{abstract}

calmidazolium; trifluoperazine; $N$-(6-aminohexyl)-5-chloro-1naphthalene-sulfonamide

IN VIVO EVIDENCE suggests that the secretion and the synthesis of renin in renal juxtaglomerular (JG) cells are concordantly regulated by the main physiological control factors $(5,20-22)$. These factors comprise the blood pressure, sodium chloride intake, sympathetic nerves, and hormones, particularly angiotensin II, the product resulting from renin activity (10).

How this parallelism between renin synthesis and renin secretion is managed on the level of JG cells is not known. Although the regulation of renin synthesis at the cellular level is not well understood, it is conceivable that renin synthesis and renin secretion are controlled by the same cellular second messenger molecules. In fact, a recent study with cultured mouse JG cells has provided evidence that adenosine $3^{\prime}, 5^{\prime}$-cyclic monophosphate (cAMP), which is considered a main regulator of renin secretion, enhanced both the secretion and the de novo synthesis rate of renin (4).

Another second messenger that is thought to be of major importance for the control of renin secretion is the intracellular concentration of calcium within the JG cells $(16,18,25)$. Opposite to other secretory cells, however, where rises of intracellular calcium initiate, facilitate, or maintain secretory events $(24,26,27)$, calcium is considered an inhibitory signal for the exocytosis of renin granules $(2,7,11)$. There is, moreover, good evidence that such an inhibitory effect of calcium is mediated by calmodulin, because several studies have shown that the inhibitory effect of calcium on renin secretion is blunted by calmodulin antagonists, which conversely increase renin secretion in perfused kidneys and in renal slices $(1,3,6,14,17,19,23,28)$.

When the importance of calcium-calmodulin for the regulation of renin secretion was considered, it appeared reasonable therefore to consider a calmodulin-activated process also as a possible denominator for renin secretion and renin synthesis.

To address this question we have utilized primary cultures of mouse JG cells, which have recently been shown to be a suitable model to study the cellular regulation of renin secretion and renin synthesis in parallel (4). In those cultures we have examined the effects of the three structurally different calmodulin antagonists calmidazolium, trifluoperazine and $\mathrm{N}$-(6-aminohexyl)-5chloro-1-naphtalenesulfonamide (W-7) on renin secretion and renin synthesis.

We found that these calmodulin antagonists caused a marked enhancement of renin secretion that was paralleled by an inhibition of renin synthesis. The decreased renin synthesis appeared to result from a general inhibition of protein synthesis in the cultured cells, which in turn, however, was not the reason for the enhancement of renin secretion.

\section{METHODS}

Culture of mouse JG cells. Mouse JG cells were isolated as described previously (4). For one cell preparation, six male C57Bl6 mice (4-6 wk old) which had free access to normal food and water were killed by cervical dislocation. The kidneys were extirpated, decapsulated, and minced with a razor blade. The minced tissue was incubated during gentle stirring for $70 \mathrm{~min}$ at $37^{\circ} \mathrm{C}$ in a solution of $50 \mathrm{ml}$ buffer $1[130 \mathrm{NaCl}, 5 \mathrm{KCl}, 2$ $\mathrm{CaCl}_{2}, 10$ glucose, 20 sucrose, and $10 \mathrm{mM}$ tris(hydroxymethyl)-aminomethane (Tris) $\cdot \mathrm{Cl}, \mathrm{pH}$ 7.4] supplemented with $0.25 \%$ trypsin (Sigma) and $0.1 \%$ collagenase (Boehringer Mannheim, Germany).

After enzymatic dissociation, the digested tissue was sieved over a $22-\mu \mathrm{m}$ screen. Single cells passing the screen were collected, washed, and resuspended in $8 \mathrm{ml}$ of buffer 1 and then further separated using Percoll (Pharmacia, Sweden) density gradients. The obtained cell suspension was added to four tubes each containing $30 \mathrm{ml}$ of $30 \%$ isosmotic Percoll in buffer 1 . After 25 min centrifugation at $4^{\circ} \mathrm{C}$ and $27,000 \mathrm{~g}$ four cell layers with different specific renin activity were obtained.

The cellular layer $(d=1.07 \mathrm{~g} / \mathrm{ml})$ that displayed the highest specific renin activity was used for cell culture. These cells were washed in buffer 1 and resuspended in $6 \mathrm{ml}$ of RPMI 1640 medium (Amimed) containing $0.66 \mathrm{U} / \mathrm{ml}$ insulin, $100 \mathrm{U} / \mathrm{ml}$ penicillin, $100 \mu \mathrm{g} / \mathrm{ml}$ streptomycin, and $2 \%$ fetal calf serum 
(FCS). The cultures were distributed in $250-\mu$ l portions into 24-well plates and incubated at $37^{\circ} \mathrm{C}$ in a humidified atmosphere containing $5 \% \mathrm{CO}_{2}$ in air.

Experiments. Experiments on renin secretion and renin synthesis were performed after $20 \mathrm{~h}$ of primary culture. At this time the culture medium was removed, and the cultures were washed twice with methionine-free RPMI 1640 medium containing $2 \%$ dialyzed FCS. Then fresh and prewarmed methionine-free culture medium supplemented with $40 \mu \mathrm{Ci} / \mathrm{ml}\left[{ }^{35} \mathrm{~S}\right]-$ methionine (New England Nuclear), $0.66 \mathrm{U} / \mathrm{ml}$ insulin, $100 \mathrm{U} /$ $\mathrm{ml}$ penicillin, $100 \mu \mathrm{g} / \mathrm{ml}$ streptomycin, and $2 \%$ dialyzed FCS together with the drugs to be tested or their respective solvent controls were added.

Experiments implying measurement of renin synthesis were performed at least during $20 \mathrm{~h}$. At the end of the experiment (usually $40 \mathrm{~h}$ after the onset of the primary culture) supernatants were collected and centrifuged at $500-1,000 \mathrm{~g}$ and $4^{\circ} \mathrm{C}$ in a Sorvall RT6000 centrifuge to remove cellular debris. The supernatants were then stored at $-20^{\circ} \mathrm{C}$ for further processing. Cells were lysed by adding to each culture well $250 \mu \mathrm{l}$ of phosphate-buffered saline (PBS) containing $0.1 \%$ of Triton X100 and shaking for $45 \mathrm{~min}$ at room temperature. The lysed cells were stored at $-20^{\circ} \mathrm{C}$ for further processing.

Measurement of total protein synthesis. Total protein synthesis rates were estimated by measuring the ${ }^{35} \mathrm{~S}$ radioactivity precipitable by trichloroacetic acid (TCA) from lysed cells and supernatants using bovine serum albumin (BSA) as carrier. To $10 \mu \mathrm{l}$ of cell lysate or supernatant, $300 \mu \mathrm{l}$ of a $0.1 \%$ BSA solution in PBS were added. Precipitation of radiolabeled proteins was achieved by adding $1 \mathrm{ml}$ of $20 \%$ TCA in water to each sample. The samples were then placed on ice for $20 \mathrm{~min}$, and the precipitate was collected by a 20 -min centrifugation at $2,000 \mathrm{~g}$ and $4^{\circ} \mathrm{C}$. The precipitate was washed once with $3 \mathrm{ml}$ of $5 \%$ TCA in water and solubilized in $0.5 \mathrm{ml}$ of $8 \mathrm{M}$ urea. Radioactivity was measured by adding the solubilized precipitate to a liquid scintillator cocktail (Optiphase MP, LKB) and counting in a beta-scintillation counter.

Assay of protein. Protein concentration in cellular lysates was determined using the Bio-Rad protein assay kit.

Determination of renin synthesis. Renin synthesis was estimated by immunoprecipitation of renin from supernatants and cellular fractions using an antiserum directed against mouse renin. The specificity of this antiserum has been characterized previously (4).

Before immunobinding, the cellular lysates or culture media (volume $250 \mu \mathrm{l}$ ) were concentrated to a volume of 10-20 $\mu \mathrm{l}$ and then dialyzed against $2 \times 2 \mathrm{ml}$ PBS by ultrafiltration on centricon 30 membranes (Amicon) (mol mass cutoff $30 \mathrm{kDa}$ ) at $2,000 \mathrm{~g}$ in swingout buckets in a Sorvall RT6000 centrifuge at $4^{\circ} \mathrm{C}$. The dialyzed samples were then brought to a volume of $500 \mu \mathrm{l}$ with PBS supplemented with $1 \% \mathrm{BSA}$ and $0.1 \%$ normal rabbit serum and preincubated at $37^{\circ} \mathrm{C}$ for $2 \mathrm{~h}$. Each sample was then provided with $50 \mu \mathrm{l}$ of the immunoadsorbent Omnisorb cells (Calbiochem, Lucerne, Switzerland) for $1 \mathrm{~h}$ at room temperature. Omnisorb was removed by a 15 -min centrifugation at $2,000 \mathrm{~g}$ and $4^{\circ} \mathrm{C}$.

The supernatants were split into duplicates; one was incubated with rabbit antimouse renin serum at a final dilution of $1: 1,000$ at $4^{\circ} \mathrm{C}$ overnight, the other with rabbit preimmune serum at the same conditions. After incubation of the samples with Omnisorb cells for $1 \mathrm{~h}$ at room temperature, Omnisorb was removed by centrifugation as already described.

The pellets were then resuspended and washed in $2 \mathrm{ml}$ of ice-cold PBS until radioactivity in the wash solution was $<1$ $\mathrm{cpm} / \mu \mathrm{l}$ (usually after 3-4 washes). After the last wash the supernatants were carefully removed, and the pellets were dissolved in a liquid scintillator and counted in a beta-counter. Specific binding was considered the difference of counts bound by the renin antiserum and the relative control with normal rabbit serum (nonspecific binding). Nonspecific binding ranged from 500-1,200 counts/min (cpm) per culture well among the different culture preparations, and specific binding was between $17-20 \%$ of total binding.

Determination of renin secretion. Renin secretion rates were estimated from the appearance rate of renin activity in the culture medium. To minimize differences among different cell culture preparations, renin secretion rates were calculated as fractional release of total renin [i.e., renin released/(renin released + renin remaining in the cells)]. Renin activity was determined by its ability to generate angiotensin I from the plasma of bilaterally nephrectomized rats. Angiotensin I was measured by radioimmunoassay (Medipro, Teufen, Switzerland).

Trypan blue exclusion test. Viability of the cells was determined at the end of the experiments using a trypan blue exclusion test.

Statistics. Levels of significance were calculated utilizing Student's unpaired $t$ test. $P<0.05$ was considered significant.

\section{RESULTS}

To investigate the role of calmodulin activity in the regulation of the secretion and the synthesis of renin, structurally different calmodulin antagonists, namely calmidazolium (CMDZ), trifluoperazine (TFP), W-7, and $N$-(6-aminohexyl)-1-naphtalene-sulfonamide (W-5) were used at different concentrations.

On the 2nd day of primary culture, the culture medium of the JG cells was replaced by fresh medium supplemented with graded concentrations of TFP, W-7, W-5, and CMDZ, and the cells were incubated for a further 20 $\mathrm{h}$.

Under control conditions the cultured JG cells spontaneously released an average renin activity of $0.60 \mu \mathrm{g}$ angiotensin I (ANG I) per hour per $100 \mu \mathrm{g}$ of cellular protein per $20 \mathrm{~h}$, which corresponded to a fractional release of $23 \pm 1 \%$ of total renin activity (mean $\pm \mathrm{SE}, n$ $=12$ ).

CMDZ at concentrations of $100 \mathrm{nM}$ and $1 \mu \mathrm{M}$ did not influence renin secretion, but at $10 \mu \mathrm{M} \mathrm{CMDZ} \mathrm{led} \mathrm{to} \mathrm{an}$ almost complete emptying of the cellular renin stores (Fig. 1). W-7 had an effect similar to CMDZ, with a maximal stimulation of renin secretion occurring at a

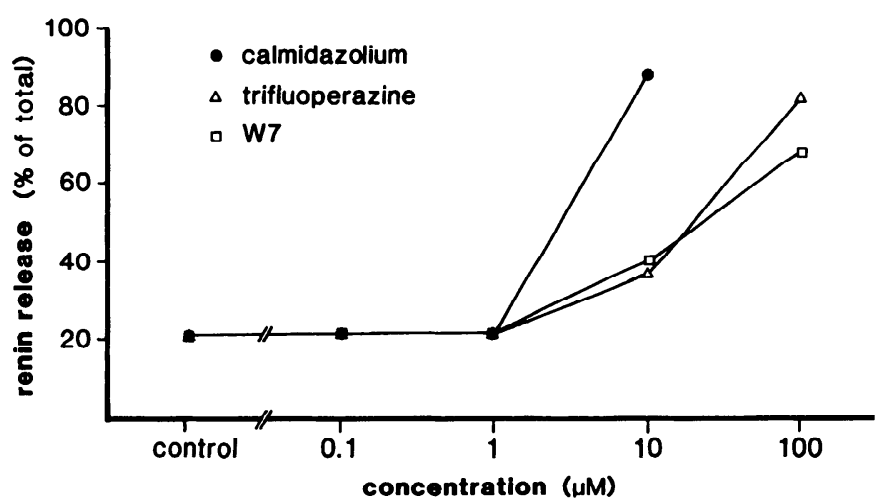

Fig. 1. Renin secretion rates from cells between 20 th and 40 th $\mathrm{h}$ of culture in presence of calmidazolium, trifluoperazine, and $N$-(6-aminohexyl)-5-chloro-1-naphthalene-sulfonamide (W-7) at different concentrations. Data are means \pm SE of 6 experiments. Error bars are covered by symbols. Stimulation of renin secretion by $10 \mu \mathrm{M}$ of each drug is significant $(P<0.05$ vs. control). 
concentration of $100 \mu \mathrm{M}$ (Fig. 1). With the same potency as $\mathrm{W}-7$, TFP $(100 \mu \mathrm{M})$ also strongly stimulated renin secretion (Fig. 1). Even at $10 \mu \mathrm{M}$ TFP caused a twofold stimulation of the renin secretion.

W-5, a calmodulin antagonist with a weaker affinity to calmodulin than W-7, had no significant effect on renin secretion at concentrations up to $100 \mu \mathrm{M}$ (not shown). Next, we examined the influence of the different calmodulin antagonists on renin synthesis by the cultured JG cells. To this end the calmodulin antagonists were used at the concentrations at which they strongly stimulated renin secretion (Fig. 1). Renin synthesis rate was estimated from the ${ }^{35} \mathrm{~S}$ radioactivity specifically bound to an antiserum against mouse submaxillary renin as described in METHODS.

Renin synthesis rate during the $20 \mathrm{~h}$ of incubation corresponded to $160 \pm 30 \mathrm{cpm}$ per $100 \mu \mathrm{g}$ of cellular protein (mean $\pm \mathrm{SE}, n=10$ ) under control conditions. Renin synthesis was not altered by $1 \mu \mathrm{M} \mathrm{CMDZ} \mathrm{or} 100$ $\mu \mathrm{M} \mathrm{W}-5$ but was almost completely suppressed by $10 \mu \mathrm{M}$ CMDZ, $100 \mu \mathrm{M}$ TFP, and $100 \mu \mathrm{M} \mathrm{W}-7$ (Fig. 2). In the presence of $10 \mu \mathrm{M}$ TFP renin synthesis was reduced to $\sim 50 \%$.

To test for the specificity of the effects on renin synthesis seen with the calmodulin antagonists, we further determined the effects of CMDZ, W-7, and TFP on total protein synthesis in the cell cultures. Total protein synthesis was estimated from the amount of ${ }^{35} \mathrm{~S}$ radioactivity precipitable by TCA.

Between the 20th and 40th h of cell culture, the total protein synthesis rate at control conditions corresponded to $9.3 \pm 0.7 \times 10^{4} \mathrm{cpm}$ per $100 \mu \mathrm{g}$ of cellular protein. Each of the calmodulin antagonists used led to a concentration-dependent inhibition of the protein synthesis in the cultures (Fig. 3).

In the presence of $100 \mu \mathrm{M} \mathrm{W}-7,100 \mu \mathrm{M}$ TFP, or 10 $\mu \mathrm{M}$ CMDZ total protein synthesis was reduced to $10 \%$ of the control value after $20 \mathrm{~h}$ of incubation. It was interesting to note the parallelism between stimulation

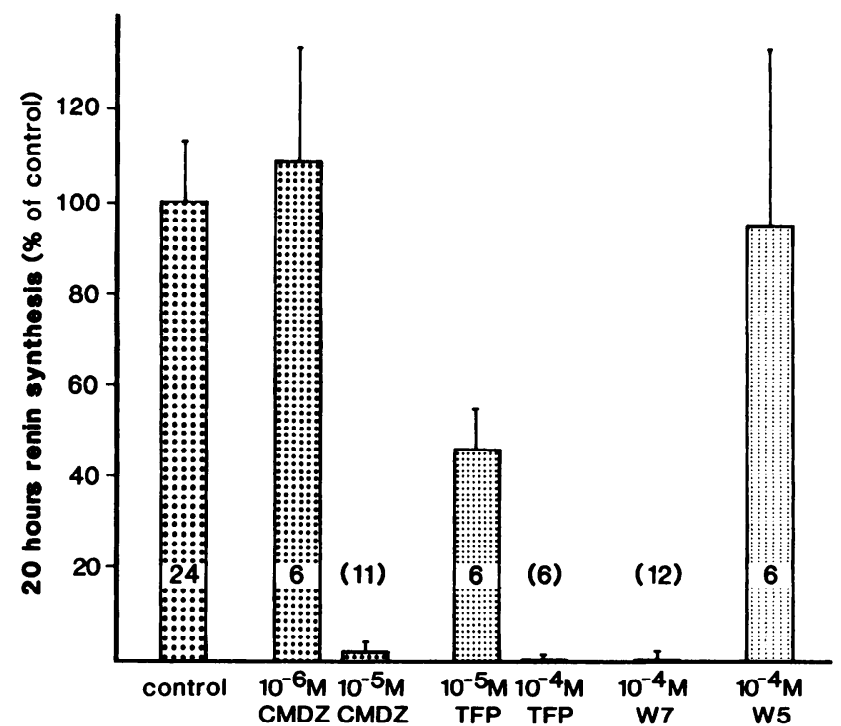

Fig. 2. Renin synthesis rates of cells between 20th and 40th $h$ of culture in presence of calmidazolium (CMDZ), trifluoperazine (TFP), W-7, and $N$-(6-aminohexyl)-1-naphtalene-sulfonamide (W-5). Data are means $\pm \mathrm{SE}$; numbers on columns indicate number of experiments.

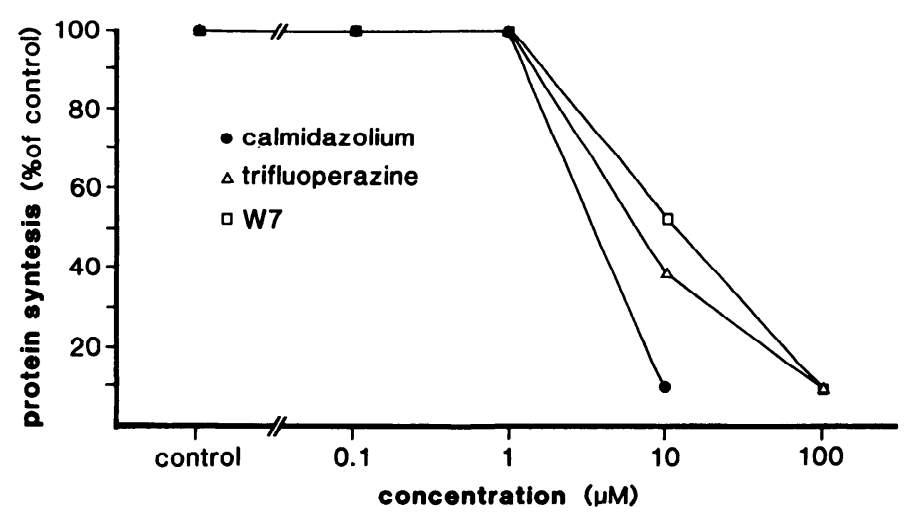

Fig. 3. Total protein synthesis rates of cells between 20 th and 40 th $\mathrm{h}$ of culture in presence of CMDZ, TFP, and W-7 at different concentrations. Data are means $\pm \mathrm{SE}$ of 6 experiments. Error bars are covered by symbols.

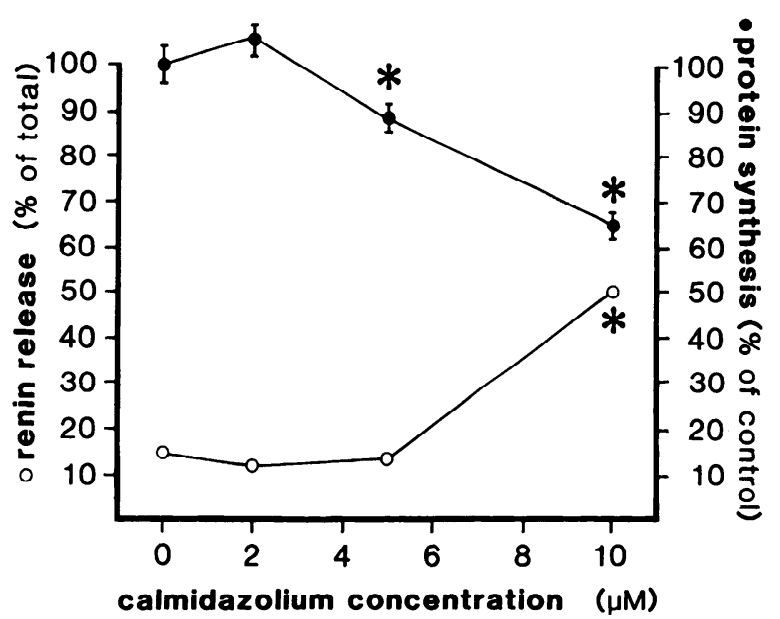

Fig. 4. Renin secretion rates and total protein synthesis rates of cultured juxtaglomerular cells in presence of different concentrations of CMDZ for $1 \mathrm{~h}$. Protein synthesis in absence of CMDZ was set to $100 \%$. Renin secretion is expressed as fractional release of total renin content. Data are means $\pm \mathrm{SE}$ of 4 experiments. ${ }^{*} P<0.05$ vs. control.

of renin secretion and inhibition of protein synthesis evoked by calmodulin antagonists; they inhibited protein synthesis by the same order of potency by which they stimulated renin secretion. Thereby the inhibitory effects on total protein synthesis and on renin synthesis exerted by the calmodulin antagonists went in parallel, leaving the ratio of renin synthesis over total protein synthesis unaltered under all experimental conditions.

A consideration of the reciprocal effects of calmodulin antagonists on renin secretion and renin synthesis led to the question of whether the stimulation of renin secretion might be secondary to the inhibition of protein synthesis. To investigate this possible relationship, two series of experiments were performed. First, the concentration dependency of CMDZ for its effects on renin secretion and total protein synthesis was determined. To this end, the cultured cells were incubated with 2,5 , and $10 \mu \mathrm{M}$ of CMDZ for $1 \mathrm{~h}$, and renin secretion and total protein synthesis were measured (Fig. 4).

When it was assumed that $10 \mu \mathrm{M} \mathrm{CMDZ} \mathrm{was} \mathrm{sufficient}$ to cause maximal stimulation of renin secretion and maximal inhibition of protein synthesis, the half-maximal effective dose $\left(\mathrm{ED}_{50}\right)$ values of $\mathrm{CMDZ}$ for stimulation 
of renin secretion and for inhibition of protein synthesis were determined to be 8 and $4 \mu \mathrm{M}$, respectively (Fig. 4), but were not significantly different.

In the second series of experiments the time dependency of the action of CMDZ on protein synthesis (Fig. $5 A$ ) and on renin secretion (Fig. $5 B$ ) was determined and was compared with the action of cycloheximide $(100 \mu \mathrm{M})$, which is an established inhibitor of protein synthesis.

As shown in Fig. 5, CMDZ $(10 \mu \mathrm{M})$ had a similar inhibitory effect on total protein synthesis as cycloheximide $(100 \mu \mathrm{M})$. After $20 \mathrm{~h}$ of incubation, both drugs led to an inhibition of protein synthesis to $\sim 10 \%$ of the respective controls. In contrast to $\mathrm{CMDZ}$, cycloheximide did not influence renin secretion (Fig. 5B). Moreover, the strong stimulation of renin secretion by CMDZ turned out to be of rapid onset; even after $1 \mathrm{~h}$ of incubation with CMDZ, renin secretion was stimulated fivefold.

Since a marked inhibition of protein synthesis as seen with CMDZ, TFP, and W-7 could be indicative of an unspecific toxic effect of these drugs, the viability of the cultured cells was routinely checked at the end of the experiments utilizing a trypan blue exclusion test.

The percentage of cells that excluded trypan blue was $80 \pm 5 \%$ (mean $\pm \mathrm{SE}$ ) among eight different cell culture preparations. In none of the experiments shown was the
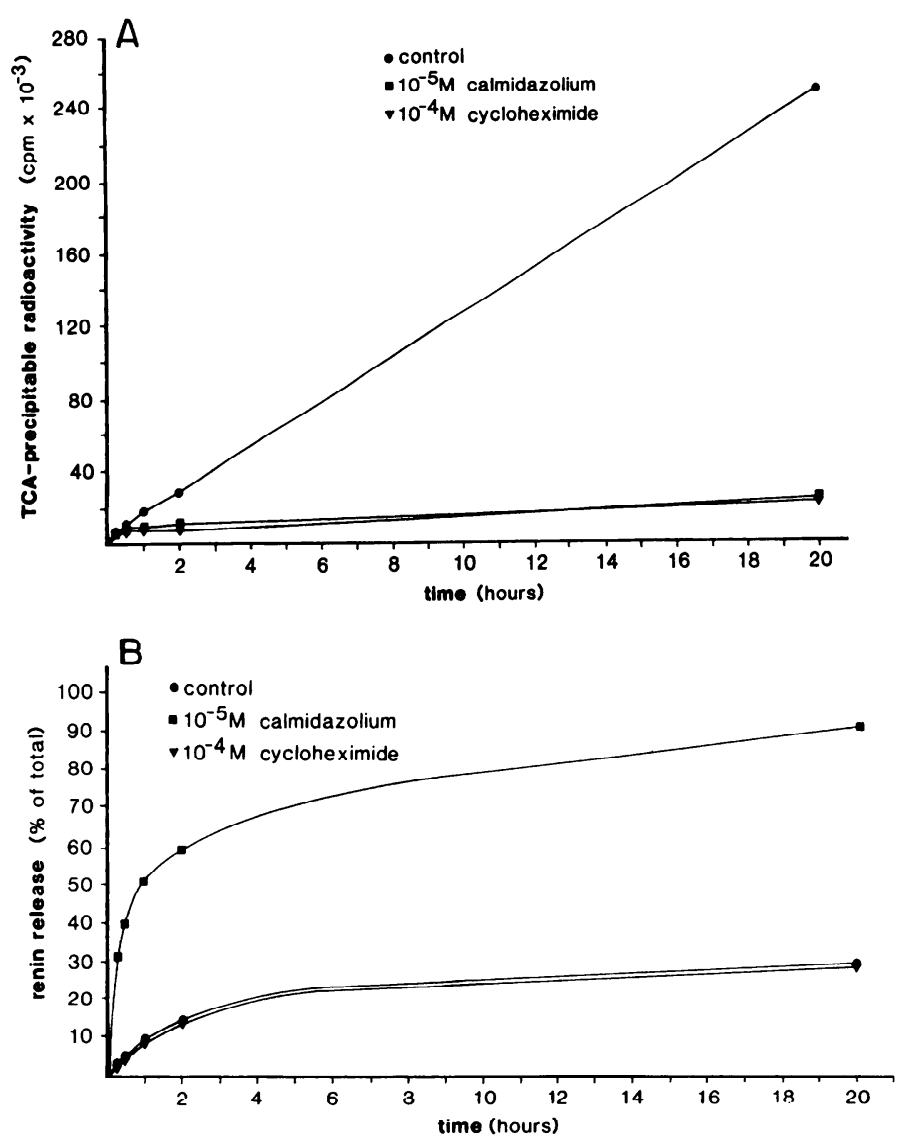

Fig. 5. A: time course of total protein synthesis of cells in presence of CMDZ $(10 \mu \mathrm{M})$ and cycloheximide $(100 \mu \mathrm{M})$. Data are means $\pm \mathrm{SE}$ of 4 experiments. Error bars are covered by symbols. $B$ : time course of renin secretion from cells in presence of CMDZ $(10 \mu \mathrm{M})$ and cycloheximide $(100 \mu \mathrm{M})$. Data are means $\pm \mathrm{SE}$ of 4 experiments. Error bars are covered by symbols. trypan blue exclusion behavior of the cells significantly different from the respective control. Also the cellular protein mass attached to the culture dishes remained unchanged at the different experimental conditions during $20 \mathrm{~h}$ of incubation.

Further evidence that the calmodulin antagonists were not primarily toxic to JG cells came from experiments in which the reversibility of the effects of calmodulin antagonists on protein synthesis was examined. For these experiments, the cultured cells were incubated for $1 \mathrm{~h}$ with $10 \mu \mathrm{M}$ CMDZ, a condition at which total protein synthesis and renin secretion were already maximally influenced (Fig. 5). Then, the culture medium was replaced with fresh medium without CMDZ and supplemented with $40 \mu \mathrm{Ci} / \mathrm{ml}$ of $\left[{ }^{35} \mathrm{~S}\right]$ methionine. Cells and supernatants were collected 20 and $45 \mathrm{~h}$ after the removal of CMDZ. As shown in Fig. 6, after a lag period the cells recovered their normal protein synthesis rates; $20 \mathrm{~h}$ after removal of CMDZ protein synthesis rate was $\sim 30 \%$ of respective controls, and after $45 \mathrm{~h}$ this percentage had increased to $60 \%$. Between the 20th and 45 th $\mathrm{h}$ after removal of CMDZ protein synthesis rates had normalized as indicated by almost identical slopes of both curves (Fig. 6).

In addition to the recovery of the total protein synthesis, the cultured cells also recovered their capability to synthesize renin; $20 \mathrm{~h}$ after removal of CMDZ, the amount of newly synthesized renin was not significantly different from the respective controls $(120 \pm 12 \mathrm{cpm} / 100$ $\mu \mathrm{g}$ protein $\times 20 \mathrm{~h}$ ).

\section{DISCUSSION}

It was the aim of this study to examine the role of calmodulin activity in the regulation of renin secretion and synthesis in renal JG cells. To this end, we used primary cultures of mouse kidney cells highly enriched in JG cells. We have shown recently that during the first days of primary culture those cultures synthesize and release renin in a regulated fashion (4).

To investigate the role of calmodulin in secretion and synthesis of renin, we used the three structurally differ-

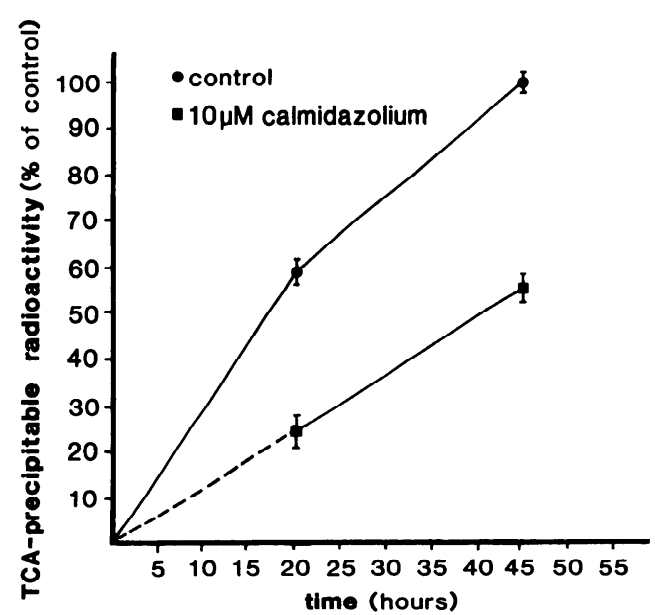

Fig. 6. Time course of total protein synthesis of cells after $1 \mathrm{~h}$ preincubation with CMDZ $(10 \mu \mathrm{M})$. Protein synthesis is given as percentage of control. Protein synthesis of control cells after $45 \mathrm{~h}$ of incubation was set to $100 \%$. Data are means \pm SE of 4 experiments. 
ent calmodulin antagonists, namely CMDZ, TFP, and W-7 at various concentrations. In agreement with studies performed with rat glomeruli (14), rat renal cortical slices $(1,3,19,23)$, isolated perfused rat kidneys $(6,28)$, and isolated rat JG cells (17), renin secretion was stimulated by calmodulin antagonists in a concentration-dependent fashion. In this study we found a rank order of potency with $\mathrm{CMDZ}>\mathrm{TFP}>\mathrm{W}-7$.

CMDZ $(10 \mu \mathrm{M})$, TFP $(100 \mu \mathrm{M})$ and $\mathrm{W}-7(100 \mu \mathrm{M})$ led to an almost complete emptying of the cellular renin stores (Fig. 1). Although all three drugs have been found to exert a number of cellular side effects with relevance for renin secretion, such as antagonizing calcium influx $(17,29)$ or inhibiting cAMP-phosphodiesterase $(8,12)$, three lines of evidence suggest that the observed effects on renin secretion were due to inhibition of calmodulin activity rather than to other side actions.

First, three calmodulin antagonists differing in their chemical structure stimulated renin secretion in a similar way with a rank of potency also known for calmodulin inhibition $(8,13)$. Secondly, W-5, a structural analogue to W-7 with lower affinity to calmodulin (13) had a markedly reduced influence on renin secretion. Finally, the potency by which renin secretion was stimulated by calmodulin antagonists is markedly greater than that reached by increasing the intracellular cAMP level with forskolin or by preventing calcium entry with ethylene $\mathrm{g}$ lycol-bis ( $\beta$-aminoethyl ether)- $N, N, N^{\prime}, N^{\prime}$-tetraacetic acid (EGTA); for comparison, in the presence of $2 \mathrm{mM}$ EGTA, the cells released $24.4 \pm 2.8 \%$ (mean \pm SE; $n=$ 4) of their total renin content within $20 \mathrm{~h}$. Saturating concentrations of forskolin $(10 \mu \mathrm{M})$ increased renin release to $45.6 \pm 3.1 \%$ of total renin (mean $\pm \mathrm{SE} ; n=4$ ), whereas CMDZ stimulated renin secretion at least fivefold, and led to a total emptying of the renin stores within several hours (Fig. $5 B$ ).

In the same concentration range in which they were active on renin secretion, the calmodulin antagonists also led a dose-dependent inhibition of renin synthesis (Fig. 2). All three calmodulin antagonists, moreover, led to a dose-dependent inhibition of total protein synthesis (Fig. 3). The inhibition of renin synthesis therefore seems to be subordinated to a general inhibition of protein synthesis rather than being a specific process in JG cells.

The observation that JG cells responded to calmodulin antagonists by a rapid emptying of their renin stores and the finding that the calmodulin antagonists strongly attenuated protein synthesis in JG cells raised the suspicion that the calmodulin antagonists could be toxic to JG cells, thus damaging the cells and causing a nonspecific release of intracellular components including stored renin.

However, we did not perceive obvious signs of detrimental effects of calmodulin antagonists. The amount of cell mass attached to the culture wells remained unchanged in the presence of calmodulin antagonists even after $20 \mathrm{~h}$ of incubation; moreover, the calmodulin antagonists did not alter the trypan blue exclusion behavior of the cells, which is considered a sign of cellular integrity (15). In addition, the inhibitory effects of calmodulin antagonists on renin and total protein synthesis turned out to be reversible within several hours (Fig. 6).
All together, these findings suggest that the powerful enhancement of renin release by calmodulin antagonists was not the result of cell damage. Nonetheless, the parallelism observed between inhibition of protein synthesis and stimulation of renin secretion seen with each type of calmodulin antagonists raised the question of whether the increase of renin secretion evoked by CMDZ, TFP, or W-7 could have been the consequence of the inhibition of protein synthesis.

Effective block of protein synthesis by cycloheximide, however, did not influence renin secretion during $20 \mathrm{~h}$ of incubation (Fig. 5); moreover, inhibition of protein synthesis occurred even at a concentration of CMDZ that did not influence renin secretion (Fig. 4). These findings suggest that it was not the inhibition of protein synthesis that had mediated the increase of renin release in response to calmodulin antagonists.

When all the findings are taken together, it appears likely therefore that it was the calmodulin activity that exerted a strong inhibitory effect on the exocytosis of renin containing vesicles. We presently cannot distinguish whether this is a direct effect of calcium-calmodulin activity on renin granules or on the cell membrane or is indirectly mediated, for instance, by influencing the activity of ion pumps or phosphodiesterases for cyclic nucleotides. In fact, it is conceivable that inhibition of the calmodulin-activated cAMP-phosphodiesterase could lead to a rise of cellular levels of cAMP, which in turn is known as a powerful stimulatory signal for renin secretion (10). Although we cannot rule out a contribution of this pathway to the effects of calmodulin antagonists on renin secretion, other pathways must also be involved, because calmodulin antagonists are more powerful activators for renin secretion as are stimulators of cAMP formation. In any case it will be of interest to elucidate in future experiments the molecular mechanism by which calmodulin exerts its powerful control on the exocytosis of renin.

Considering the initial question, namely whether calmodulin activity could be a linking denominator for renin secretion and renin synthesis, we think our findings do not support such a role of calmodulin. Under all experimental conditions renin synthesis changed in relation to total protein synthesis. In the case that calmodulin activity would exert a specific effect on renin synthesis but would be required for protein synthesis in general in JG cells, then a relative change of renin synthesis in proportion to total protein synthesis should be expected in the presence of calmodulin antagonists. This behavior, however, was not seen with the cultured JG cells, which on the other hand are capable of increasing their renin synthesis rate about threefold in response to stimulators of cAMP formation (4).

We gratefully acknowledge the expert technical assistance provided by Wolfgang Baier and the artwork done by Christian Gasser. We thank Hannelore Trommer for secretarial help.

This study was financially supported by Swiss National Science Foundation Grant 31-26381.89.

Address for reprint requests: A. Kurtz, Physiologisches Institut, Universität Regensberg, Universitätsstrasse 31, W-8400 Regensberg, FRG.

Received 5 June 1991; accepted in final form 15 October 1991. 


\section{REFERENCES}

1. Antonipillai, I., and R. Horton. Role of extra- and intracellular calcium and calmodulin in renin release from rat kidney. Endocrinology 117: 601-606, 1985.

2. Churchill, P. C. Second messengers in renins secretion. Am. J. Physiol. 249 (Renal Fluid Electrolyte Physiol. 18): F175-F184, 1985.

3. Churchill, P.C., and M. C. Churchill. Effects of trifluoperazine on renin secretion of rat kidneys slices. J. Pharmacol. Exp. Ther. 224: 68-72, 1983.

4. Della Bruna, R., F. Pinet, P. Corvol, and A. Kurtz. Regulation of renin secretion and renin synthesis by second messengers in isolated mouse juxtaglomerular cells. Cell. Physiol. Biochem. 1: 98-110, 1991.

5. Dzau, V. J., D. W. Burt, and R. E. Pratt. Molecular biology of the renin-angiotensin system. Am. J. Physiol. 255 (Renal Fluid Electrolyte Physiol. 24) F563-F573, 1988

6. Fray, J. C. S., D. J. Lush, D. Share, and A. N. D. Valentine. Possible role of calmodulin in renin secretion from isolated rat kidneys and renal cells: studies with trifluoperazine. J. Physiol. Lond. 343: 447-454, 1983.

7. Fray, J. C. S., D. J. Lush, and A. N. D. Valentine. Cellular mechanism of renin release. Federation Proc. 42: 3150-3154, 1983.

8. Gietzen, K., I. Sadorf, and H. Bader. A model for the regulation of the calmodulin-dependent enzymes erythrocyte $\mathrm{Ca}^{2+}$ transport ATPase and brain phosphodiesterase by activates and inhibitors. Biochem. J. 207: 541-548, 1982.

9. Gietzen, K., A. Wuthrich, and H. Bader. A new powerful inhibitor of red blood cell $\mathrm{Ca}^{++}$-transport ATPase and of calmodulin-regulated functions. Biochem. Biophys. Res. Commun. 101: 418-425, 1981.

10. Hackenthal, E., M. Paul, D. Ganten, and R. Taugner. Morphology, physiology, and molecular biology of renin secretion. Physiol. Rev. 70: 1067-1116, 1990.

11. Hackenthal, E., and R. Taugner. Hormone signals and intracellular messengers for renin secretion. Mol. Cell. Endocrinol. 47: $1-12,1986$.

12. Henquin, J. C. Effects of trifluoperazine and pimozide on stimulus-secretion coupling in pancreatic B-cells. Biochem. J. 196: 771$780,1981$.

13. Hidaka, H., Y. Sasaki, T. Tanaka, T. Endo, S. Ohno, Y. Fujii, and T. Nagata. $N$-(6-aminohexyl)-5-chloro-1-naphtalenesulfonamide, a calmodulin antagonist, inhibits cell proliferation. Proc. Natl. Acad. Sci. USA. 78: 4354-4357, 1981.

14. Kawamura, M., and T. Inagami. Calmodulin antagonists stimulate renin release from isolated rat glomeruli. Endocrinology 112: $1857-1859,1983$

15. Kuchler, R. J. Biochemical Methods in Cell Culture and Virology.
Stroudsburg, PA: Dowden, Hutchinson \& Ross, 1977.

16. Kurtz, A., and R. Penner. Angiotensin II induces oscillations of intracellular calcium and inhibits anomalous inward rectifying potassium current in renal juxtaglomerular cells. Proc. Natl. Acad. Sci. USA 86: 3423-3427, 1989.

17. Kurtz, A., J. Pfeilschifter, and C. Bauer. Is renin secretion governed by the calcium permeability of the juxtaglomerular cell membrane? Biochem. Biophys. Res. Commun. 124: 359-366, 1984.

18. Kurtz, A., J. Pfeilschifter, A. Hutter, C. P. Bührle, R. Nobiling, R. Taugner, E. Hackenthal, and C. Bauer. Role of protein kinase $\mathrm{C}$ in vasoconstrictor caused inhibition of renin release from isolated juxtaglomerular cells. Am. J. Physiol. 250 (Cell Physiol. 19): C563-C571, 1986.

19. Matsumara, Y., N. Miyawaki, and S. Morimoto. Effects of $\mathrm{W}-7$ and $\mathrm{W}-5$ on renin release from rat kidney cortical slices. Jpn. J. Pharmacol. 36: 268-271, 1984.

20. Moffet, R. B., R. A. McGowan, and K. W. Gross. Modulation of kidney renin messenger RNA levels during experimentally induced hypertension. Hypertension Dallas 8: 874-882, 1986.

21. Morimoto, S., K. Yamamoto, K. Horiuchi, H. Tanaka, and J. Ueda. A release of renin from dog kidney cortex slices. Jpn. J. Pharmacol. 20: 536-545, 1970.

22. Nakamura, K., F. Soubrier, J. Menard, J. J. Panthier, F. Rougeon, and P. Corvol. Nonportional changes in plasma renin concentration, renal renin content and rat renin messenger RNA. Hypertension Dallas 7: 855-859, 1985.

23. Park, C. S., T. W. Honeyman, E. S. Chung, J. S. Lee, D. H. Sigmon, and J. C. S. Fray. Involvement of calmodulin in mediating inhibitory action of intracellular $\mathrm{Ca}^{2+}$ on renin secretion. $\mathrm{Am}$. J. Physiol. 251 (Renal Fluid Electrolyte Physiol. 20): F1055-F1062, 1986.

24. Penner, R., and E. Neher. The role of calcium in stimulussecretion coupling in excitable and non-excitable cells. J. Exp. Biol. 139: 329-345, 1988.

25. Pfeilschifter, J., A. Kurtz, and C. Bauer. Inhibition of renin release by platelet activating factor (acetylglyceryl ether phosphorylcholine) in cultured rat juxtaglomerular cells. Biochem. Biophys. Res. Commun 127: 903-910, 1985.

26. Rasmussen, H. The calcium messenger system. N. Engl. J. Med. 314: 1164-1170, 1986.

27. Rubin, R. P. The role of calcium in the release of neurotransmitter substances and hormones. Pharmacol. Rev. 22: 389-428, 1970.

28. Schwertschlag, U., and E. Hackenthal. Short communication: trifluoperazine antagonizes inhibition of renin release by angiotensin II. Clin. Exp. Pharmacol. Physiol. 10: 605-608, 1983.

29. Seeman, $\mathbf{P}$. The membrane actions of anesthetics and tranquilizers. Pharmacol. Rev. 24: 583-655, 1972. 